\title{
МОВА ПРОПОВІДЕЙ ПАТРІАРХА ФІЛАРЕТА
}

Борита В. М. Мова проповідей Патріарха Філарета.

У статті досліджено структурно-граматичні та семантико-синтаксичні особливості проповідей Патріарха Філарета. Розглянуто та проаналізовано найбільш поширені снтаксичні конструкції.

Ключові слова: проповідь, конструкція, лінгвістичні, граматичні та стилістичні особливості.

Борыта В. М. Язык проповедей Патриарха Филарета.

В статье исследованы структурно-грамматические и семантико-синтаксические особенности проповедей Патрирха Филарета. Рассмотрены и проанализированы наиболее распространенные снтаксические конструкции.

Ключевые слова: проповедь, конструкция, лингвистические, грамматические и стилистические особенности.

Boryta V. M. The language of Patriarch Filaret's sermons.

The article deals with the research of structural and grammatical and semantic and syntactic peculiarities of Patriarch Filaret's sermons. The author investigates the most widespread grammatical constructions and analyzes definite syntactic structures.

Key words: sermon, construction, linguistic, grammatical and stylistic peculiarities.

Кінець минулого століття - початок нинішнього позначений жвавим інтересом дослідників до різних аспектів вивчення конфесійного стилю. Значна увага при цьому надається дослідженню його мовних особливостей.

Мова релігії (стилю сфери релігії), зазначає І. В. Богачевська, це «специфічна, конфесіоналізована внаслідок своєї кодифікації знакова система, що виникає, як правило, на основі якоїсь природної національної мови (або мов) i виконує в релігійному спілкуванні когнітивну i комунікативну функції» $[1$, с. 5$]$.

Сьогодні активно досліджується мова Святого Письма, Учительних Свангелій, Житія святих, пастирських послань, духовної літератури, молитви, проповідей тощо. Метою пропонованої статі $є$ дослідження мовностильових особливостей проповідей Патріарха Філарета.

Основним жанром церковного красномовства була i залишається проповідь. Вона $\epsilon$ особливим видом усного монологічного мовлення, спрямованим до вірян задля того, аби навернути їх до християнського віровчення, викликати почуття вдячності Богу, виховати почуття єдності у вірі, терпіння в ім'я потойбічного життя [4, с. 220].

Проповіді присвячуються певним темам життя духовного і земного, тому в них переважають репрезентативні (відповідальність за істинність висловлювання), директивні (змусити слухача виконати певну дію), комісивні (обов'язок дотримуватися певної лінії поведінки), ілокутивні (мовленнєві) акти [4, с. 223].

Проповіді поділяються на літургійні, догматичні, морально-повчальні. Текст проповіді має канонічну будову, вступ, у якому викладається зміст 
(епіграф), витлумачується сам вступ і оголошується тема проповіді; виклад предмета (це короткий трактат) і закінчення (епілог).

Комунікативна організація тексту проповіді визначається передусім тим, що вона спрямована не у сферу мови, а у сферу мовлення. Основною комунікативною метою проповіді $€$ вплив на адресатів, спонукання їх до фізичних чи духовних дій. За характером мовленнєвого стимулу у проповіді виокремлюють риторичність, спонукальність, звернення до адресатів, що стимулює активізацію духовної або фізичної діяльності останніх.

Основне призначення проповідника - так вплинути на слухачів, щоб підняти їхні душевні сили на добрі діяння для інших і облагородження себе самого. Досягти цього можна тільки за допомогою майстерного використання мовних засобів, тому дуже важливою для проповідника $є$ робота зі словом.

Завдання церковної проповіді полягає в поясненні кодифікованих Святим Письмом основних положень християнської філософії 3 подальшими настановами вірян про стиль життя та поведінки.

Л. І. Мацько зауважує, що «у проповідях мовні елементи конфесійності мають поєднуватися 3 елементами художності та публіцистичності: комунікативний намір, бажаний ефект, комунікативні імплікатури, інтра- i трансконцепти, просторово-локальний i часовий дейксис, емотивність i спонукальність, експресія, образність, переконання» [5, с. 225].

Відомий історик української церкви й української мови Іван Огієнко писав: «Уже з XVI ст. Українська Церква кохалася в церковній проповіді, i то в живій народній, чого зовсім не знала, наприклад, Церква Московська. За XVI-XVII віків, коли на Українську Церкву з усіх боків нападали різні вороги, у нас особливо розвинулася церковна проповідь, пам'ятками чого зосталися десятки грубезних томів проповідей. У нашій Церкві була навіть окрема посада «казнодія», проповідника, так що проповідь стала важливою частиною богослужб» [6, с. 79].

Проповідництво серед українського православного духовенства завжди було яскравим і тому являло світові визначні постаті, серед яких можна назвати й Предстоятеля Української Православної Церкви, Святішого Патріарха Київського і всієї Русі-України Філарета. Його проникливе слово, пов'язане із сьогоденням, звернене до всіх вірян. Більшість проповідей Патріарха Філарета- це не просто переказ євангельських подій, розповідь про християнські чесноти, а глибокий аналіз і суголосність із сьогоденням Біблії та повчань святих.

До основних мовностильових особливостей текстів проповідей Філарета належить маркована лексика, яку в українській літературній мові називають конфесійною, а також своєрідні семантико-синтаксичні конструкції.

Характерними лексичними ознаками конфесійної мови П. С. Дудик іменує «уживання «поважних» слів і висловів, за якими здавна закріпилося 
церковно-релігійне значення; велику кількість своєрідних абстрактних найменувань; широке використання церковнослов'янізмів і лексем, запозичених із Біблії, зокрема в українському перекладі» [2, с. 92].

Найвиразніше тексти проповідей характеризує лексичний склад. Лексика проповідей тематично спеціальна, стандартна, дещо незвична, особлива. Серед лексико-семантичних груп типовими $є$ слова для найменування Бога та потойбічного світу; стосунків людини і Бога; назви служителів релігії; назви таїнств, елементів християнської обрядовості; назви постів; назви різних конфесійних реалій; деякі поняття неправославних релігій; назви богослужбових відправ; найменування одягу духовних осіб, частин їх убрання; назви предметів християнського обряду і т. ін.

Спостереження за граматичними, зокрема синтаксичними, особливостями текстів проповідей свідчить про наявність великої кількості конструкцій, об’єднаних однією семантикою і подібним емоційно-оцінним забарвленням.

Синтаксичною особливістю проповіді $\epsilon$ обов'язкова наявність спонукальних конструкцій в епілозі - моральному додатку. Тому найбільш поширеними в текстах проповідей Філарета $\epsilon$ структури, що передають спонукання. Як засвідчує дослідження, для текстів проповідей характерними є спонукальні конструкції, які виражають прохання, поради, заохочення, благання, застереження тощо. Наприклад: Не уподібнюйтесь, браття і сестри, тим, хто, сідаючи за стіл, не молиться Богу (6, с. 137); Уцей день простімо один одного Воскресінням Христовим $і$ будемо благати Господа, щзоб Він зміинив Своєю Божественною благодаттю намі душевні і тілесні сили і благословив нас на добрі справи (6, с. 47); Не будемо жс забувати заповідь Господа нашого Ісуса Христа: "Шукайте ж спериу Царства Божсого і правди Його, і все изе додасться вам» (6, с. 107).

Широко представленими у проповідях є питальні конструкції, побудовані переважно за принципом запитання-відповідь. Використовуючи у своїх виступах такі структури, Патріарх Філарет тим самим прагне зосередити увагу адресатів на порушуваній ним проблемі, спонукати їх до роздумів щодо одержаної інформації. Так, у проповідях виявляємо питальні конструкції на зразок: Чого ж ми чекаємо від Того, Хто плоттю заснув у гробі? Ми сподіваємося, ми шукаємо того, щуо обіияв Господь; ми шукаємо душевного спокою. Але чи знаходимо ми те, чого шукаємо? Так, знаходимо! (8, с. 117); Невже нема щастя на землі? Ні, щзастя є, воно изілком досяжне: треба тільки знати, де і як його знайти! (8, с. 7); Чи ж може християнин звертатися до різних вішунів: ворожок, тих, які викликають духів та інших? Християнин не повинен удаватися за допомогою до віщунів (8, с. 286); Як жити нам на цій Землі, щзо збожеволіла від зла? Святитель Ігнатій каже, щуо ті, хто дійсно будуть служити Богу, не відкриватимуть себе людям і не будуть здійснювати серед них чудес (8, с. 15). 
Варто звернути увагу також на емоційну виразність поданих структур. Широко й активно у своїх проповідях Філарет послуговується риторичними запитаннями, що дає змогу максимально емоційно зосередити адресатів, спонукає їх до роздумів, сприяє узагальненню тієї чи іншої інформації. Наприклад: Якщцо зовнішній вигляд гнівливої людини такий неприємний, то щзо відбувається в ї̈ бідній душі? (7, с. 70); Чи потрібно говорити про тих жінок, які присвятили своє життя і труди поширенню християнської віри $i$ тим самим облагодіяли свої народи? (7, с. 60).

Характерними для досліджуваного матеріалу є риторичні запитання 3 єдинопочатками: Премудрий Сирах каже: «I хто може дослідити великі діла Його? Хто може виміряти силу величі Його? I хто можсе розповісти про милості Його» (8, с. 140).

М. У. Каранська зауважує, що «у кінці таких речень добре було б ставити знак питання зі знаком оклику, щоб відрізняти їх від питальних та окличних речень» $[3$, с. 16].

Властивими для текстів проповідей $є$ побудови, що вирізняються повторюваними початковими синтаксичними структурами. У Філарета такі конструкції часто подані з тим самим службовим словом. наприклад: Чому n'яниці пиячать, наркомани вживають наркотики, а блудники перелюбствують? Тому, що Бога немає перед ними. Чому злодій грабує $i$ злочинець вбиває? Тому, щио Бога немає перед ними. Чому зростає злочинність в Україні ц̆ в усьому світі? Тому, щчо Бога немає перед злочинцями (7, с. 74); Ось лік святих патріархів $i$ праотців, які вірили Божественним обітуванням про пришестя Спасителя. Ось лік святих пророків, щ⿻о провіщуали пришестя Христове. Ось лік святих апостолів, які, залишивии все пішли за Христом. Ось лік святих мучеників, які за сповідання віри Христової були піддані жорстоким стражданням $i$ в невимовних муках віддали своє життя за Христа. Ось лік святих пастирів $i$ святителів, які словом і ділом, вченням і життям своїм навчали і навчають живої віри у Христа. Ось лік святих праведників, які жили у цуьому гріховному світі, але були не від світу цүього $і$ жили не духом цүього cвimy (7, с. 92-93).

Часті службові слова у таких побудовах несуть на собі смислове та емоційне навантаження, акцентують увагу на певних особах чи явищах, мають уточнювальне значення, виконують функцію актуалізації змісту.

Серед побудов із єдинопочатками у проповідника виявляємо складнопідрядні умовні речення, які виражають пряму зумовленість. При цьому «для підкреслення підстави, потрібної для вираження висновку в головній частині, диференційні сполучники можуть супроводжуватися лексемами значить, отже, виходить. Створюються поєднання на зразок

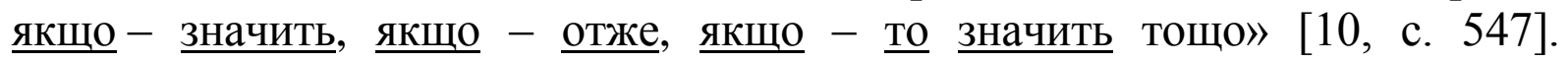
Наприклад: Якщчо Христос воскрес, - значить $i$ ми, хоч $і$ помремо, але безумовно воскреснемо. Якщо Христос воскрес, - значить, ми спасенні $i$ 
маємо можливість благодаттю Святого Духа очищатися від гріха. Якщи Христос воскрес, - значить, правда перемогла неправду, любовненависть, добро - зло. Якиц Христос воскрес - цее значить, щуо все, щуо Він відкрив людям про Бога, про людину $і$ світ, є істина. Якщц Христос воскрес - це значить, щзо ми маємо надію на життя вічне. Якщи Христос, розіп'ятий на хресті, помер і воскрес-значить, Він є істинний Син Божий, наш спаситель і Визволитель (7, с. 43-44).

Типовими для текстів проповідей $є$ структури, які виражають порівняльні відношення. Основним засобом для оформлення порівняння в таких структурах виступає сполучник як у поєднанні з корелятом так: Як лазерний промінь, проходячи крізь тіло, життя не бачить, так і розум, скільки б не розмірковував, сили віри не осягне (7, с. 41); Як через гріхопадіння перших людей у нашу природу ввійшов закон смерті, так через Воскресіння Христове в цъю ж природу ввійшов закон Воскресіння (7, с. 44); Як пожежа, коли ї̈ не гасять, знищує багато будинків; так $і$ гнів - якщо швидко не припинити його, то він багато принесе зла... (7, с. 70).

Порівнюючи сьогодення українського суспільства 3 часом життя Ісуса Христа, проповідник переносить тогочасні події на нинішній час, проводячи при цьому своєрідну часову паралель. При побудові таких конструкцій використовується синтаксичний паралелізм: Сучасне становище в Украӥні можна порівняти з Голгофою. Як тоді на Голгофі йшла боротьба людськой ненависті з Христовою любов'ю, так і тепер у суспільстві йде жорстока боротьба добра $i$ зла, світла $i$ темряви (7, с. 46); Протягом майже 2000-літньої історії були гоніння на Церкву, виникали єресі й розколи; всередині самої Церкви йшла боротьба за владу. Ось і тепер православна Церква в Украӥні розділена на частини; iде боротьба за побудову єдиної в Украӥні православної Церкви (7, с. 140) та ін.

Звичайне місце головного компонента у таких порівняльних структурах на початку речення, він виражає рему, а підрядний компонент порівняльно уточнює значення реми. Проте, як бачимо, для вираження теми вислову підрядний компонент проповідник вживає на першому місці.

Мовностильова організація текстів проповідей вирізняється своєрідними граматичними особливостями. Найбільш виразно в око впадають питально-риторичні конструкції, детальніший розгляд яких нами заплановано в подальших наукових розвідках.

Отже, мова проповідей Патріарха Філарета характеризується особливою, тематично спеціальною, не властивою для текстів інших стилів лексикою, широким використанням старослов'янізмів і лексем, запозичених iз Біблії, а також - використанням різнопланових семантико-синтаксичних конструкцій, об'єднаних однією семантикою і подібним емоційно-оцінним забарвленням, яким притаманні висока i водночас своєрідна ритмомелодика, елементи урочистості, підсиленого зосередження уваги, спонукання, порівняння, прощальності тощо. 


\section{Література}

1. Богачевська І. В. Філософський аналіз мови релігії в контексті вчення О. О. Потебні : автореф. дис. на здобуття наук. ступеня канд. філос. наук : спец. «Філософія» / І. В. Богачевська. - К., 1998. - 19 с.

2. Дудик П. С. Стилістика української мови : [навч. посібник] / П. С. Дудик. - К. : ВЦ «Академія», 2004. - 368 c.

3. Каранська М. У. Синтаксис сучасної української літературної мови : [навч. посібник] М. У. Каранська. - К. : Либідь, 1995. - 312 с.

4. Мацько Л. І. Риторика : [навч. посібник] / Л. І. Мацько, О. М. Мацько - К. : Вища шк., 2003. - 311 с.

5. Мацько Л. І. Стилістика української мови : [підручн. для студ. філол. спец. вищ. навч. закл.] / Л. І. Мацько, О. М. Сидоренко, О. М. Мацько; за ред. Л. І. Мацько. - К. : Вища школа, 2003. - 462 с.

6. Огієнко І. І. Українська церква / І. І. Огієнко // Нариси з історії української православної церкви : у 2-х т. - К., 1993. - Т. 1. - С. 79.

7. Патріарх Філарет. Проповіді : у 2-х т. / Патріарх Філарет - К. : ВВ УПЦ Київського Патріархату, 1999. - T. 1. - 434 c.

8. Патріарх Філарет. Проповіді : у 2-х т. / Патріарх Філарет - К. : ВВ УПЦ Київського Патріархату, 2000. - T. 2. -447 c.

9. Петришина О. І. Мова проповідей Йосифа Сліпого: автореф. дис. на здобуття наук. ступеня канд. філол. наук: спец. 10.02.01 - «Українська мова» / О. І. Петришина. - Івано-Франківськ, 2008. - 20 с.

10. Слинько I. I. Синтаксис сучасної української мови: Проблемні питання : [навч. посібник] / I. І. Слинько, Н. В. Гуйванюк, М. Ф. Кобилянська. - К. : Вища школа, 1994. - 670 с.

11. Струганець Л. Особливості репрезентації сакральної лексики в українській лексикографії / Л. Струганець // Мандрівець. - 2000. - №5-6. - С. 47-51.

12. Українська мова : [енциклопедія] / [Редкол.: В. М. Русанівський (співголова), О. О. Тараненко (співголова), М. П. Зяблюк та ін.]. - [2-ге вид., випр. і доп.] - К. : Вид-во «Укр. енцикл.» ім. М. П. Бажана, 2004. -824 с.: іл.

Стаття надійшла до редакції 14.11.2011 p. 